NSL 03394

\title{
$\alpha$-TOXIN PERMEABILIZED RAT PHEOCHROMOCYTOMA CELLS: A NEW APPROACH TO INVESTIGATE STIMULUS-SECRETION COUPLING
}

\author{
GUDRUN AHNERT-HILGER ${ }^{1}$, SUCHARIT BHAKDI ${ }^{2}$ and MANFRED GRATZL ${ }^{1, *}$ \\ 'Abteilung für Klinische Morphologie der Universität Ulm, Oberer Eselsberg, D-7900 Ulm, and 'Institut für \\ Medizinische Mikrobiologie der Universität Giessen, Frankfurter Strasse 107, D-6300 Giessen (F.R.G.)
}

(Received April 1st, 1985; Accepted April 16th, 1985)

Key words: $\alpha$-toxin - permeabilization $-\mathrm{Ca}^{2+}-$ exocytosis - pheochromocytoma - rat

The channel forming $\alpha$-toxin of Staphylococcus aureus (about $50 \mu \mathrm{g} / \mathrm{ml}$ ) markedly reduces the $\mathrm{Ca}^{2+}$ requirement for dopamine release by the rat pheochromocytoma cell line (PC 12). Maximal secretion by intact cells requires approximately $1 \mathrm{mM} \mathrm{Ca}^{2+}$, whereas release by $\alpha$-toxin-permeabilized cells can already be triggered with $\mu \mathrm{M}$ concentrations of $\mathrm{Ca}^{2+}$. The latter process reaches a plateau at about $1 \mu \mathrm{M}$ free $\mathrm{Ca}^{2+}$ and increases again with $10-20 \mu \mathrm{M}$ free $\mathrm{Ca}^{2+}$. The sensitivity to low concentrations of $\mathrm{Ca}^{2+}$ indicates that the toxin, as a selective cell membrane permeabilizing agent, can be used as a powerful instrument to study stimulus-secretion coupling.

In order to gain access to the intracellular sites involved in the regulation of exocytosis, secretory cells have been permeabilized using different techniques $[3,4,10,13]$. However, the results obtained with cells subjected to high-voltage discharges or treated with membrane perturbants such as digitonin and saponin are contradictory. For example, the release of secretory products observed with electrically permeabilized chromaffin cells [1] was inhibited by digitonin, a substance used by other groups for permeabilization $[4,13]$. The conflicting data obtained so far may be mainly due to the unspecificity of the procedures used. In particular, substances such as digitonin may affect cell components other than the cell membrane, thereby compromising functions other than membrane permeability in the cells.

Here, we report an alternative approach to circumvent these problems. A rat pheochromocytoma cell line (PC 12) has been used as a secretory system, and $\alpha$-toxin from Staphylococcus aureus as a cell membrane permeabilizing agent. This toxin forms stable, transmembrane channels with an effective diameter of 2-3 nm $[2,6]$, which are too small to permit passage of toxin monomers into the cell. The effects of this toxin would therefore be expected to be confined strictly to the cell plasma membrane. $\alpha$-Toxin as a selective membrane permeabilizing agent indeed appears to be an excellent tool for studying' stimulus-secretion coupling. In this contribution, we demonstrate that $\mu \mathrm{M}$ concentrations of free $\mathrm{Ca}^{2+}$ are sufficient to trigger dopa-

\footnotetext{
* Author for correspondence at: Abteilung Klinische Morphologie der Universität Ulm, Postfach 4066,
} D-7900 Ulm, F.R.G. 
mine release in $\alpha$-toxin-treated cells, whereas millimolar extracellular concentrations $\mathrm{Ca}^{2+}$ are required for secretion elicited by depolarization.

Exocytosis is paralleled by an increase in the cytoplasmic concentration of free $\mathrm{Ca}^{2+}$ in chromaffin and other secretory cells (cf. ref. 11). Primary cultures from adrenal medulla or the rat pheochromocytoma cell line PC 12 [9] are often used to study secretion. The release of dopamine from PC 12 cells due to nicotinic stimulation or

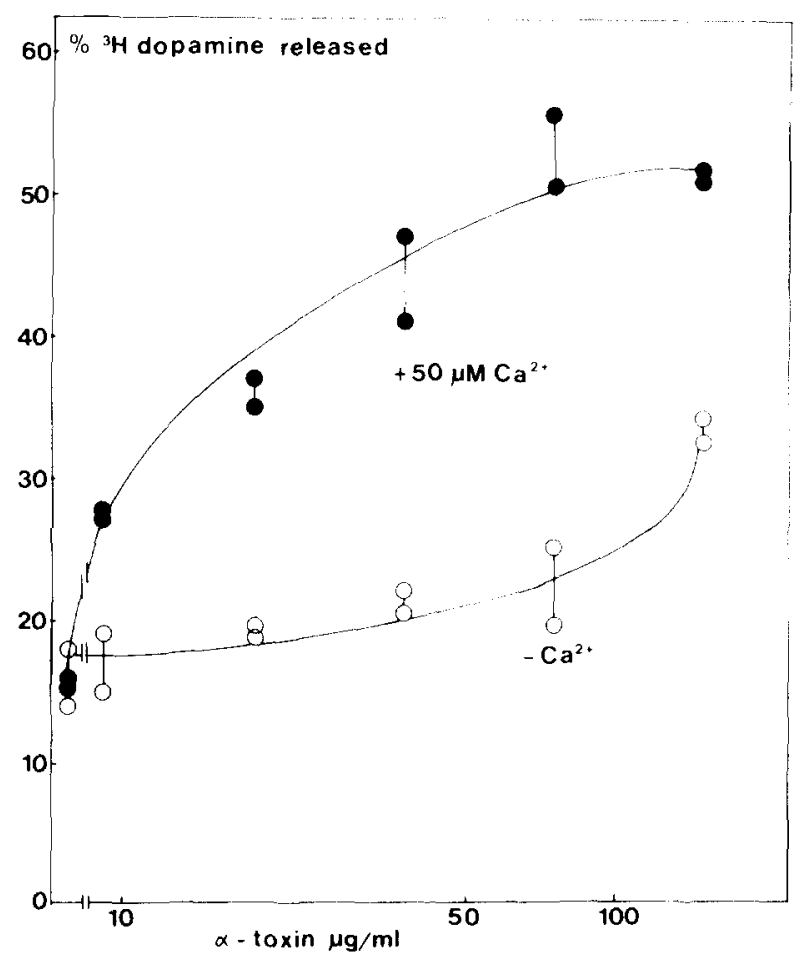

Fig. 1. Effect of different concentrations of $\alpha$-toxin on the [ $\left.{ }^{3} \mathrm{H}\right]$ dopamine release of $\mathrm{PC} 12$ cells in the presence $(\Theta)$ or absence $(O)$ of $\mathrm{Ca}^{2+}$. $\alpha$-Toxin from Staphylococcus aureus was purified as described [6]. The PC 12 cells were kindly supplied by $\mathrm{H}$. Thoenen (Max Planck Institut für Psychiatrie, Martinsried, F.R.G.). Cells were grown on plastic dishes in Dulbecco's modified Eagle's medium supplemented with $10 \%$ horse serum $-5 \%$ fetal calf serum in a humidified atmosphere of $10 \% \mathrm{CO}_{2}$ as described [8]. For loading, the cells were first incubated with $0.25 \mu \mathrm{M}\left[{ }^{3} \mathrm{H}\right]$ dopamine (spec.act. $11.5 \mathrm{Ci} / \mathrm{mmol}$ ) for $2 \mathrm{~h}$ in culture medium without serum. Subsequently they were washed with $\mathrm{Ca}^{2+}$-free incubation buffer $\left(\mathrm{K}^{+}\right.$glutamate 150, PIPES 10, EGTA $5 \mathrm{mM}$, pH 7.2) and resuspended in the same buffer supplemented with $0.2 \%$ bovine serum albumin. Incubation buffer with defined amounts of $\mathrm{Ca}^{2+}$ in the presence of absence of $\alpha$-toxin was added, and incubations were performed for $20 \mathrm{~min}$ at $37^{\circ} \mathrm{C}$. The exact concentration of free $\mathrm{Ca}^{2+}$ was calculated by means of a computer program as described [5] using the stability constants listed [12] and/or determined with the aid of a $\mathrm{Ca}^{2+}$-specific electrode (the necessary membranes were kindly provided by W. Simon, ETH Zürich, Switzerland). Radioactivity was determined by liquid-scintillation counting in the supernatant as well as in the cells. $\left[{ }^{3} \mathrm{H}\right]$ Dopamine released was given as percent of total present before incubation with toxin. Samples contained 50-80 $\mu$ g cell protein. The average uptake of $\left[{ }^{3} \mathrm{H}\right]$ dopamine was approximately $55 \mathrm{pmol} / \mathrm{mg}$ cell protein. 
depolarization requires $\mathrm{mM}$ concentrations of $\mathrm{Ca}^{2+}(0.5-1 \mathrm{mM})$ in the extracellular fluid (cf. ref. 9, compare Fig. 2A).

By contrast, $\mu \mathrm{M}$ concentrations of free $\mathrm{Ca}^{2+}$ were found to be sufficient to elicit release of dopamine in $\alpha$-toxin-permeabilized cells. In these experiments, $\alpha$-toxin was used at concentrations ranging from 10 to $100 \mu \mathrm{g} / \mathrm{m} 1$ with negligible changes in basal release (Fig. 1). Using these concentrations, $\mathrm{Ca}^{2+}$-dependent $\left[{ }^{3} \mathrm{H}\right]$ dopamine release was increased in a dose-dependent manner. Above $100 \mu \mathrm{g} / \mathrm{ml}, \alpha$-toxin induced a $\mathrm{Ca}^{2+}$-independent release of $\left[{ }^{3} \mathrm{H}\right]$ dopamine, probably due to general leakiness of the cells (Fig. 1).

Fig. 2 compares the amount of free $\mathrm{Ca}^{2+}$ necessary in the medium for secretion by depolarized cells as opposed to $\alpha$-toxin-permeabilized cells. Depolarization by potassium was half-maximal with a concentration of $0.5 \mathrm{mM}$ free $\mathrm{Ca}^{2+}$. Below a concentration of $0.2 \mathrm{mM}$ free $\mathrm{Ca}^{2+}$, release of $\left[{ }^{3} \mathrm{H}\right]$ dopamine was approximately the same as in the absence of $\mathrm{Ca}^{2+}$ (Fig. 2A). By contrast, very low concentrations of free $\mathrm{Ca}^{2+}$ sufficed to initiate dopamine release from $\alpha$-toxin-permeabilized cells $(37 \mu \mathrm{g} / \mathrm{ml}$ toxin). The release induced by $\mathrm{Ca}^{2+}$ reached a first plateau between 1 and $4 \mu \mathrm{M}$, and further release was induced at 5-20 $\mu \mathrm{M} \mathrm{Ca}^{2+}$ to reach maximal levels at the latter $\mathrm{Ca}^{2+}$ concentrations (Fig. 2B, compare value found with the same amount of toxin

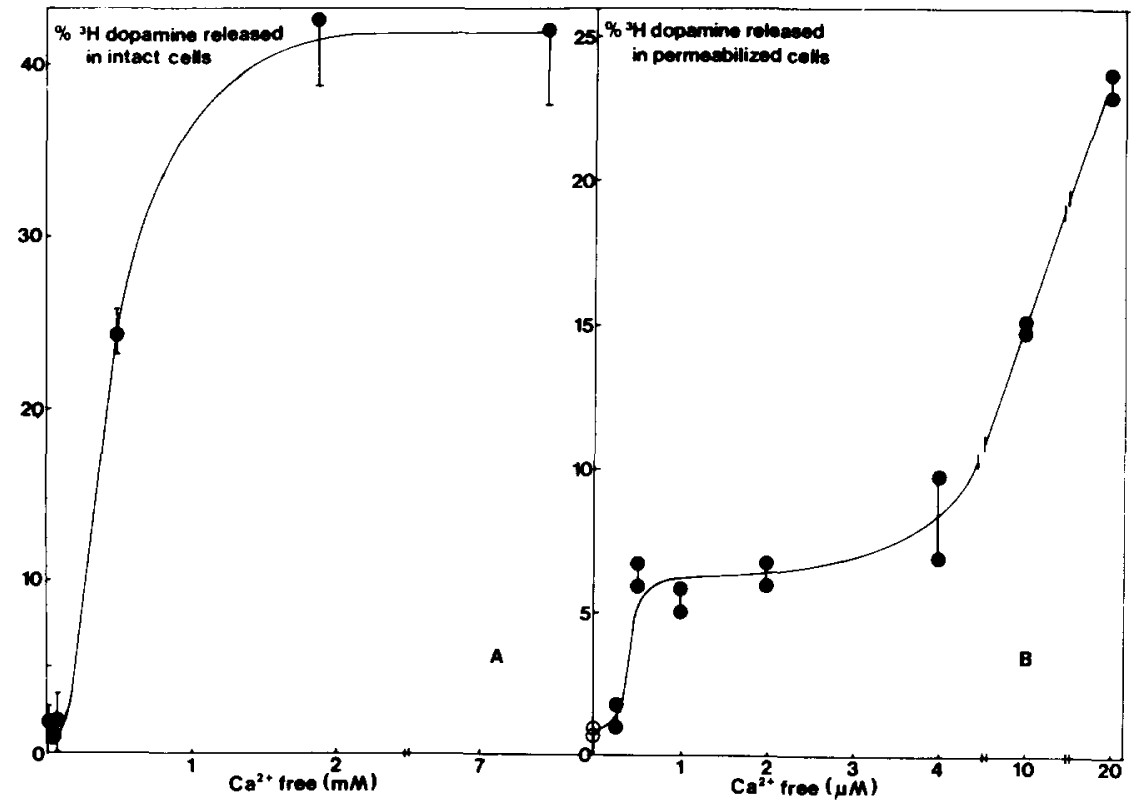

Fig. 2. $\mathrm{Ca}^{2+}$ requirement of $\left[{ }^{3} \mathrm{H}\right]$ dopamine release by PC 12 cells after depolarization $(\mathrm{A})$ and $\alpha$-toxin permeabilization (B) as a function of the free $\mathrm{Ca}^{2+}$ concentration. In $\mathrm{B}$, permeabilization buffer was slightly modified containing $0.5 \mathrm{mM}$ EGTA plus $5 \mathrm{mM}$ NTA instead of $5 \mathrm{mM}$ EGTA (see legend to Fig. 1). The basal release of $\left[{ }^{3} \mathrm{H}\right]$ dopamine in the absence of $\mathrm{Ca}^{2+}(\mathrm{A})$ or $\alpha$-toxin $(B)$ were $15.6 \pm 1.7(\mathrm{n}=3)$ or 18 $\pm 1.7 \%(n=16)$, respectively. These values were substracted from the release observed in the presence of $\mathrm{Ca}^{2+}$ or $\alpha$-toxin $(37 \mu \mathrm{g} / \mathrm{ml})$. 
at a free $\mathrm{Ca}^{2+}$ concentration of $50 \mu \mathrm{M}$ in Fig. 1). The first increase was observed with a half-maximal free $\mathrm{Ca}^{2+}$ concentration of $0.5 \pm 0.2 \mu \mathrm{M}(\mathrm{n}=5)$. It is of interest that intracellular free concentrations of $\mathrm{Ca}^{2}+$ in chromaffin cells indeed have been found to rise from 0.1 to approximately $0.5 \mu \mathrm{M}$ under physiological stimulation as determined with the sensitive intracellular $\mathrm{Ca}^{2+}$ indicator Quin 2 [11].

The elucidation of the chain of events taking place between recognition of the stimulus and release of the secretory product deserves different experimental approaches. Intact cells are certainly too complex to permit delineation of these events. On the other hand, experiments with isolated membranes involved in the physiological fusion reaction only allow the investigation of certain aspects of the secretory process [7]. We therefore feel that the introduction of selective membrane-permeabilizing reagents as described for $\alpha$-toxin in this paper provides a generally useful approach to the study of stimulus-secretion coupling.

The authors are indebted to Mrs. R. Gruber and Mr. P. Welk for skilful technical assistance, and Mrs. B. Mader for the preparation of the manuscript. These studies were supported by the Deutsche Forschungsgemeinschaft (SFB 47 and Gr 681/2-2).

1 Baker. P.F. and Knight, D.E., Calcium control of exocytosis and endocytosis in bovine adrenal medullary cells. Phil. Trans. R. Soc. Lond. B. 296 (1981) 83-103.

2 Bhakdi, S. and Tranum-Jensen, J., Mechanism of complement cytolysis and the concept of channelforming proteins, Phil. Trans. R. Soc. Lond. B, 306 (1984) $311 \cdots 324$.

3 Brooks, J.C. and Treml, S., Effect of trifluoperazine and calmodulin on catecholamine secretion by saponin-skinned cultured chromaffin cells, Life Sci., 34 (1984) 669-674.

4 Dunn. L.A. and Holz, R.W.. Catecholamine secretion from digitonin-treated adrenal medullary cells. J. Biol. Chem., 258 (1983) 4983-4993.

5 Flodgaard, H. and Torp-Pedersen, C., A calcium ion-dependent adenosine triphosphate pyrophosphohydrolase in plasma membrane from rat liver, Biochem. J., 171 (1978) 817-820.

6 Füssle, R., Bhakdi, S., Sziegoleit, A., Tranum-Jensen, J., Kranz, T. and Wellensiek, H.-J., On the mechanism of membrane damage by the Staphylococcus aureus $\alpha$-toxin, J. Cell Biol., 91 (1981) 83-94.

7 Gratzl, M., Schudt, C., Ekerdt, R. and Dahl, G., Fusion of isolated biological membranes. In: E.E. Bittar (Ed.), Membrane Structure and Function, Vol. 3, John Wiley, New York, 1980, pp. 59-92.

8 Greene, L.A. and Tischler, A.S., Establishment of a noradrenergic clonal line of rat adrenal pheochromocytoma cells which respond to nerve growth factor, Proc. Natl. Acad. Sci. USA, 73 (1976) 2424 2428.

9 Greene, L.A. and Tischler, A.S., PC 12 pheochromocytoma cultures in neurobiological research, Adv. Cell. Neurobiol., 3 (1982) 373-407.

$10 \mathrm{Knight,} \mathrm{D.E.} \mathrm{and} \mathrm{Baker.} \mathrm{P.F.,} \mathrm{Calcium-dependence} \mathrm{of} \mathrm{catecholamine} \mathrm{release} \mathrm{from} \mathrm{bovine} \mathrm{adrenal}$ medullary cells after exposure to intense electric fields, J. Membrane Biol., 68 (1982) $107 \cdots 140$.

11 Knight, D.E. and Kesteven, N.T., Evoked transient intracellular free $\mathrm{Ca}^{2+}$ changes and secretion in isolated adrenal medullary cells, Proc. R. Soc. Lond. B, 218 (1983) 177-199.

12 Sillen, L.G. and Martell, A.E., Stability constants of metal-ion complexes. Chem. Soc. (Lond), Suppl. (1971).

13 Wilson, S.P. and Kirshner, N., Calcium-evoked secretion from digitonin-permeabilized adrenal medullary cells, J. Biol. Chem., 258 (1983) 4994-5000. 